\title{
Nurse care practices in the Family Health Strategy
}

\author{
Práticas de cuidado da enfermeira na Estratégia Saúde da Família \\ Prácticas de cuidado de la enfermera en la Estrategia Salud de la Familia
}

\begin{abstract}
Flavia Pedro dos Anjos Santos',,I, Sonia Acioli', Vanda Palmarella Rodrigues", Juliana Costa Machado", Moema Santos Souza", Tatiana Almeida Couto"

' Universidade do Estado do Rio de Janeiro, School of Nursing, Postgraduate Program in Nursing. Rio de Janeiro, Brazil.

"Universidade Estadual do Sudoeste da Bahia, Department of Health. Jequié, Bahia, Brazil.

How to cite this article:
Santos FPA, Acioli S, Rodrigues VP, Machado JC, Souza MS, Couto TA. Nurse care practices in the Family Health Strategy.
Rev Bras Enferm [Internet]. 2016;69(6):1060-7. DOI: http://dx.doi.org/10.1590/0034-7167-2016-0273
\end{abstract}

Submission: 06-17-2016

Approval: 08-19-2016

\section{ABSTRACT}

Objective: to analyze the practices of care of nurses working in teams of the family health strategy, from the perspective of users. Method: qualitative research conducted with 34 registered users in seven family health units of a municipality of Bahia from June to December 2014. The results were organized by the technique of content analysis. Results: users showed satisfaction with the nurse care due to listening, warmth and resolution of their health needs, despite the emphasis on procedures and programs targeted to populational groups. The dissatisfaction stems from the authoritarian, prescriptive and inflexible attitude in the nurse care. It was also emphasized that the home visits are directed to the bedridden and more restricted to preventive actions. Educational activities occur during the nursing consultation and in the health unit. Conclusion: there is urgent need of redefining the care as a structuring axis of the nurse practice.

Descriptors: Nursing Care; Community Health Nursing; Primary Care Nursing; Primary Health Care; Family Health.

\section{RESUMO}

Objetivo: analisar as práticas de cuidado de enfermeiras que atuam nas equipes da Estratégia Saúde da Família, sob a ótica de usuários. Método: pesquisa qualitativa realizada com 34 usuários cadastrados em sete Unidades de Saúde da Família de um município baiano entre junho e dezembro de 2014. Os resultados foram organizados pela técnica de análise de conteúdo. Resultados: os usuários mostraram satisfação com o atendimento da enfermeira em virtude da escuta, acolhimento e resolubilidade de suas necessidades de saúde, apesar da ênfase em procedimentos e programas direcionados aos grupos populacionais. A insatisfação decorre da postura autoritária, prescritiva e inflexível no cuidado produzido pela enfermeira. Destacaram ainda que as visitas domiciliares são direcionadas aos acamados e de forma mais restrita às ações preventivas. As ações educativas ocorrem durante a consulta de enfermagem e na unidade de saúde. Conclusão: urge a ressignificação do cuidado como eixo estruturante da prática da enfermeira.

Descritores: Cuidados de Enfermagem; Enfermagem em Saúde Comunitária; Enfermagem de Atenção Primária; Atenção Primária à Saúde; Saúde da Família.

\section{RESUMEN}

Objetivo: analizar las prácticas de cuidado de enfermeras actuantes en los equipos de Estrategia Salud de la Familia según visión del usuario. Método: investigación cualitativa efectuada con 34 usuarios registrados en siete Unidades de Salud de la Familia de municipio bahiano, entre junio y diciembre de 2014. Resultados organizados por análisis de contenido. Resultados: los usuarios mostraron satisfacción con la atención de la enfermera por haber sido escuchados, acogidos, y por resolverse sus necesidades de salud, a pesar del énfasis en procedimientos y programas orientados a grupos poblacionales. La insatisfacción deriva de posturas autoritarias, prescriptivas e inflexibles en la atención de la enfermera. Destacaron que las visitas domiciliarias están orientadas a pacientes en cama y, más restrictivamente, a acciones preventivas. Las acciones educativas suceden durante la consulta de enfermería en la unidad de salud. Conclusión: urge la resignificación del cuidado como eje estructural de la práctica de la enfermera.

Descriptores: Atención de Enfermería; Enfermería en Salud Comunitaria; Enfermería de Atención Primaria; Atención Primaria de Salud; Salud de la Familia. 


\section{INTRODUCTION}

Care is present in the development of the very human being in terms of continuity of life as a condition for survival ${ }^{(1-2),}$, prior to any professional exercise, as it is closely connected to the history of mankind.

Thus, two interdependent guidelines are related to care: the first seeks to ensure the continuity of life through actions that ensure the maintenance of vital signs, with emphasis on biological issues. The second is based on seeking to eliminate the aspects that can lead to death, being influenced by the establishment of the clinic, with emphasis on disease and medical specialties ${ }^{(2)}$.

It is observed that both guidelines reveal the relation between care and nursing, with the first translating into an object of nursing study and work, inseparable from the professional activity ${ }^{(3)}$.

Therefore, care constitutes the essence of the daily practice of nurses, founded on which the objective is to replace a fragmented and biologicist approach to care with a more comprehensive approach to the human being in the subjective and social issues.

Such aspect contrasts to the Cartesian model that undervalues the unique character of the person and the humanitarian values ${ }^{(4)}$, a fact that contributes to the technicist and fragmented care practice dissociated from the sociohistorical and subjective context of the social subjects.

Thus, the nurse care practice requires the appropriation of ethical, humanitarian solidarity and citizenship values, with the purpose of building new forms of action and providing comprehensive care, with appreciation and respect for the health service user ${ }^{(5)}$.

In Brazil, the nurse has excelled as a professional who acts directly or indirectly in the process of management and implementation of the Unified Health System (SUS) and, in the context of the Ministerial Programs, is inserted in the multidisciplinary team of the Family Health Strategy (FHS).

This strategy was established by the Ministry of Health in 1994, and was initially named as Family Health Program (PSF) and, later, was instituted as a priority strategy for expansion and consolidation of the basic care, being guided by the principles of universality, bond, humanization, social participation, continuity of care, among others ${ }^{(6)}$.

A research conducted in Primary Health Care (PHC) units in London, England, showed the comprehensiveness of the nurse work in comprising case management, clinic, care directed to social demands of users, showing that the home care stems from the cooperation between social services and other team members, in addition to constant assessment of health conditions, hygiene, alimentation, and ability for self-care ${ }^{(7)}$.

In the context of provision of care to users of health services, light technologies are characterized by practices of care, bond, empowerment, sensitive listening, that is, relational technologies. Light-hard technologies are related to well structured knowledge such as medical clinic and epidemiology and the hard technologies are the organizational equipment, standards and structures ${ }^{(8)}$.

Nurse care practice requires the use of these technologies with greater emphasis on relational technologies, since they are essential for greater dialogue with users of health services, enabling the nurse to know the users' expectations with regard to their practices.

The term user will be used in this study to refer to persons who use the services offered by SUS, both in basic health unit and hospital, considering that using the healthcare system is a right of the population and a duty of the State ${ }^{(9)}$.

Nurses, in using their knowledge to provide service to users, exercises respect for the human being and citizen, valuing this person in planning their actions in order to legitimize that their practices have a more participatory character.

In this sense, this research may lead to reflections and discussions on the practice of nurses working in the Family Health teams from the perspective of users, which may contribute to (re)directing their practices, advancing to the ethical dimension of care.

Thus, the study aimed to analyze the care practices of nurses working in Family Health Strategy teams, from the perspective of users.

\section{METHOD}

\section{Theoretical framework and type of study}

Descriptive research of qualitative approach ${ }^{(10)}$ founded on the theoretical-methodological framework of Waldow ${ }^{(1,11)}$, Collière $^{(2,12)}$ and Bardin ${ }^{(10)}$.

After data analysis and interpretation, the following categories emerged: Family Health nurse care; home care: strategy for nurse care practice; and educational activity in the context of FHS nurse practice.

\section{Methodological procedures}

\section{Study scenario}

This study was conducted in seven Family Health Units (FHU) in the urban area of a municipality in southwest Bahia, Brazil. The inclusion criteria to select FHUs were: complete minimum team, according to the criteria recommended by the Ministry of Health; and FHUs in the urban area, with two teams.

\section{Data source}

The inclusion criteria established for participants in the study were: users registered for over one year in the aforementioned FHUs; and aged over 18 years. Exclusion criteria: users with difficulty to maintain verbal communication or any health problems that hindered the participation in the interview, such as mental disorder, among others.

\section{Data collection and organization}

The data were collected in the period from June to December 2014, using semi-structured interviews with 34 users. The data collection instrument was composed of questions about demographic characterization of participants and trigger questions about the care practices of FHS nurses.

The interviews were recorded and had mean duration of 30 minutes.

\section{Data analysis}

To organize the empirical data, we used thematic content analysis based on extensive readings of interviews, considering 
the objectives and theoretical framework ${ }^{(1-2,10-12)}$ with identification of the central themes and relevant aspects.

\section{Ethical aspects}

The research project was approved by the Research Ethics Committee of the Universidade Estadual do Sudoeste da Bahia, considering the aspects addressed by Resolution $466 / 2012$ on research with human beings of the National Health Council(13). After approval, data collection was carried out with clarification to participants as to the objectives, the proposed methodology and the risks and benefits of the research, and participants signed the free and informed consent.

Anonymity was ensured by identifying participants with the letter " $\mathrm{R}$ " for respondent and a number that corresponded to the order of interview.

\section{RESULTS}

Of the 34 participants in the research, 29 are women, with the majority being: mulatto (13), married (15), housewives (14), with complete secondary education (12), income of up to one minimum wage (19), does not receive social assistance (22). With mean of: 48 years of age, ranging from 20 to 82 years of age, four children, 17 years of residence in the area of the FHU and nine years of registration in the FHU.

Next, the results are analyzed according to the categories established:

\section{Category 1: Care provided by Family Health nurse}

The reports showed that users were sometimes satisfied and sometimes dissatisfied with the nurse care practices.

FHS users reported that they are satisfied with the nurse care, due to the attention and willingness to listen to the perceived needs, according to the following reports.

[...] I think it's great, because she takes care of our whole family, treats us very well, [...] She is a person who [...] always serves very well [...]. (R2)

She (nurse) never served us in a bad mood [...] never unwillingly [...] I feel very good when I come to see her [...] I relax [...]. She gives me advice, talks to me [...] I never came here to return without being served, without rescheduling to another day, without having a reply [...]. (R6)

Ever since she started working here her care in relation to me and my son has always been great [...]. She always treated me well [...] I think she is a great nurse [...]. (R9)

The participants showed satisfaction in relation to the nurse care, emphasizing the nursing procedures and the service of nurses in programs related to prenatal care, hypertension, diabetes, prevention, and child health.

[...] she serves in prenatal care, helps my mother, hypertension [...] my father [...] my children, everybody [...] talks about the diseases [...] if she is doing something, she asks to wait, and she helps [...] gets involved, tries to help with all the things that I bring. (R2)
[...] I think she worked very well [...] on the day that I went there for preventive care, she explained some things. I think she's got great care, she explains things to us. (R7)

She takes good care of us [...] serves us very well. On the right day, she doesn't fail. And she collects our blood, weighs us, I am diabetic and have high blood pressure [...]. (R23)

[...] It starts from applying a bandage to prenatal care, because it is the nurse that does this prenatal procedure [...]. (R24)

We highlight in the reports of respondents satisfaction towards the service, taking into account the priority in care due to personal interests.

[...] she treated me badly, now when I go there because she knows my son now she treats me better. After that, I managed to have better access to her [...] I always do. When I can't at that moment, but she reschedules so I [sic] can go another time or on another day [...]. (R26)

[...] especially now that I am a member of the Council (Local Health Council), or also because [...] we have priority in service. But she serves well. Since I as member of the Council the people have no complaint [...]. (R32)

Users also pointed out that the practice of the nurse presents permeated by humanization, warm care, listening and bond.

She listens, takes good care. (R9)

She does everything with love [...] taking care of us. (R12)

[...] We already have a closer bond with her (nurse) [...] whenever she can she is guiding us, helping us [...]. (R15)

She listens, talks to us. I like her way. (R17)

She (nurse) serves more openly. Talking about the kid, asking if everything's okay. Asking if there's been any problem [...]. She lets us [...] express ourselves. (R18)

She asks, listens [...]. She listens to people's complaints. (R30)

On the other hand, the study showed that the users' dissatisfaction in relation to nurses results from their authoritarian and prescriptive attitude that makes it difficult to meet their health needs.

[...] She (nurse) is very authoritarian, a bit of a notch of superiority even knowing us [...] if I go on the right day, if it's been booked everything okay [...] 'cause if it ain't been booked she always puts some kinda obstacle [...] If ya don't come on the right day, "only next month", if ya ain't got no medication [...] I ain't talk a lot with her [...] I feel that she doesn't have a lotta care [...]. (R5)

[...] it's been some time that we come that there's even a correct service [...] due to the fact that I'm not hypertensive or diabetic I don't have any priority. (R20) 
[...] I feel ashamed with her [...] because the times I got to go, that I needed, with much difficulty [...] when I want something, I fight. So, because I fight a lot, sometimes I get it, sometimes I don't [...]. (R26)

\section{Category 2: Home care: strategy for nurse care practice}

Users pointed out that the home care appointment conducted by a nurse is intended to serve bedridden persons or those who who cannot go to the health unit.

The nurse [...] never came to my house. My mother got sick here, because diabetes dropped too much, no one ever came here to know [...]. Only if the person is bedridden [...] she comes to see [...]. (R25)

She usually goes to the house of people [...] who are bedridden [...]. (R26)

A nurse in my house is very rare [...] when my grandmother was alive, when she really needed, then yeah. My family [...] called for the nurse and then they went there. Take the pressure, sometimes, when she couldn't come to the health unit [...]. (R28)

On the other hand, the respondent pointed out that the home care appointment conducted by a nurse has preventive character, with emphasis on breast and prostate cancer.

[...] She came here only once [...]. She came to talk about the importance of prevention [...]. If my husband is in the proper age for prostate exam [...]. (R17)

The respondents also pointed out that the nurse has not been providing home care service.

[...] She never came to my house [...] I would really like it [...] She is a Nurse [...] that's very good to us. And if she did come here it would be even better, to instruct us [...]. (R18)

The nurse never came over no. Only the health agent [...]. (R29)

[...] it's not been occurring (home care) [...]. It should be done systematically. Even because the patient feels much more comfortable at home to receive the nurse [...] to tell all the problems [...]. (R31)

\section{Category 3: Educational activity in the context of the FHS nurse practice}

Users pointed out that educational guidelines are provided in consultation with the nurse.

She's very attentive with me, because I have to take the medicine for high blood pressure [...]. She instructs me [...] to eat all those things I can eat [...] asks me to, whenever I feel something, I come see her [...]. (R6)

[...] She instructs, talks, explains [...] tells us to go for a walk often, 'cause she says it's good for me and my health [...]. I think she instructs well. (R14)
[...] it's a service that helps to take care of our health [...] she makes an effort so that we understand [...] If we need some guidance, we have to ask her. 'Cause everything we ask her, she explains. (R18)

She talks with us, which is the most important [...]. She explains to me, guides me in everything. (R27)

The study determined that users do not participate in educational activities carried out at FHUs.

Here at the clinic, I myself have never come to a meeting scheduled by the nurse. (R1)

[...] my mother always participates [...] but I've never participated [...]. But my sister has participated. There's one that had a mammography exam, ultrasound exam. But I've never come [...]. They held it in the church [...] a very big event, many people were helped there [...]. (R26)

[...] They give a talk, but sometimes I don't participate [...]. But there's plenty of lectures here about all types of subjects [...]. I've just come to two of 'em, which were the ones on diabetes and breast cancer [...]. (R30)

Because there is no fostering [...] to stimulate the community to participate in these actions. I particularly don't participate. (R31)

\section{DISCUSSION}

The study showed the users' satisfaction with the nurse care due to the willingness, attention, listening and dialogue established between nurse, users and families. Moreover, they relate the nurse care practice to procedures such as measuring blood pressure, capillary glycaemia, applying dressing and serving in programs related to prenatal care, hypertension, diabetes, preventive care, dispensation of medicines, among others.

Nursing care includes performing technical procedures in conjunction with the adoption of attitudes consistent with humanitarian principles, that ensure the maintenance of respect, dignity and responsibility among persons involved in the care relationship ${ }^{(14)}$.

Although they report that the nurse care includes family members, it seems that such care emphasizes the biomedical model, which may preclude the comprehensiveness of care beyond the knowledge and the intervention on the sociocultural, political, economic and spiritual aspects inherent in the context of family.

The research showed that the family approach in the care provided by nurses and physicians in the FHU was also little present in the individual care, with an approach exclusively focused on the individual, emphasizing the complaint of the current illness. This justifies that the difficulty of implementing a family approach in individual service stems from the need to know all members of the family, which seems to immobilize the professionals who do not incorporate the centrality in the family and prevents that it is seen as the center of attention ${ }^{(15)}$.

The study also showed that in the nursing and medical appointments with persons with hypertension, for example, in which case there is family diathesis, the approach remained 
focused on the individual, observing that the dietary and hygienic guidelines recurrently focused on the sick individual, excluding the family from the context of prevention ${ }^{(15)}$.

It is emphasized the need for a comprehensive practice of care that goes beyond the procedures and techniques, so the care is permeated by the establishment of bond and coresponsibility of the user with his or her health and by the guarantee of the right to health.

The nursing health care, in its individual and collective dimensions, has been redefining knowledge and practices, in order to prioritize the discussion of senses and significances related to the construction of subjects to provide a comprehensive care, which should align with the principle of integrality, advocated by SUS as a fundamental mechanism to strengthen the other two principles, universality and equity ${ }^{(16)}$.

Redirecting health care to integrality and equity implies reorganizing the practices of FHS teams, so their attention is focused on the families in a given geosocial territory and so they consider the health needs of these families as needs of social reproduction ${ }^{(17)}$.

In this perspective, the integrality of care depends on the redefinition of practices, with the creation of bond, warm care and autonomy, founded on the valuation of subjectivities inherent in health work and in the unique needs of the subjects, as starting points for any intervention, building the possibility of user-centered care $^{(18)}$.

User-centered intervention must be able to enable the individual's autonomy in his or her way of living, without losing sight of the care dimension that must be present in any health care action. Dialogue and negotiation, marked by intersubjectivity, enable tracing paths that lead to resolution of the needs presented in the meeting between health worker and SUS user ${ }^{(16)}$.

Nurse care must be guided by the ethical dimension and by the centrality of the relationship with the other, so as to contribute to the construction of subjective and transforming relations that provide users with quality of life in the perspective of integrality of care ${ }^{(19-20)}$.

Another important aspect emphasized by the participants of the study referred to the facilitation in receiving service due to close relationship with the nurse, by virtue of personal privileges and the user's position as local health adviser, which enabled the priority in receiving care from the nurse at the FHU.

In the study, it was shown that the nurse can establish a more horizontal relationship with users as a result of the warm care, sensitive listening, dialogue and guidance, showing interest in their complaints, a fact that contributes to the establishment of the bond with users.

The nurse in employing dialogue, sensitive listening and warm care in the care practices has the opportunity of knowing the conditions of life and health of the population, leading to a climate of trust and mutual respect that enables the resolution of the health issues and needs identified by both ${ }^{(5)}$.

In order for nurses to develop their practices more efficiently, it is imperative that users express themselves, considering that this moment is an opportunity to value the uniqueness of each user, thus contributing to the establishment of mutual responsibility for the care provided and received.
In the users' reports, we also identified the conduct of technical procedures and nursing appointments permeated by involvement between nurse and users, which contributes to strengthening the bond as well as to recognize the potential of nurse practices, which are not restricted to technical procedures, but are closely connected to the subjective and relational dimension of care.

Thus, the employment of light, light-hard and hard technologies is necessary for the provision of care; however, the proper use of light-hard and hard technologies should be observed lest a fragmented and biologicist care is provided. On the other hand, light technologies are conducive to a logic of care that values the singularities and fosters a more humanized and efficient dimension in health care ${ }^{(8)}$.

Care, in order to transcend the technical procedures, requires the involvement of the nurse with the person who is attended, by means of touch, affection, listening and valuation of the psychoemotional aspects in the individual and family context. To this end, nurse training must focus on theoretical and philosophical dimensions of care so as to recover the essence of humane care as unifying focus of nursing ${ }^{(11)}$.

In this context, it should be noted that academic education has an essential role in the construction of a body of scientific knowledge that can relate competences and abilities to the social, cultural and spiritual dimension of human beings, understanding such beings as unique in their integrality, in order to provide the nurse with means to develop practices that give answers consistent with the health and welfare needs of the population and of the contemporary society ${ }^{(19,21)}$.

On the other hand, the results of the study highlighted the dissatisfaction of users with the assistance of the nurse, as the same, in some moments, is authoritarian and establishes rules that hamper the care of their health needs, such as service exclusively on scheduled date, only prioritization of people with hypertension and diabetes, among others, emphasizing the management practice of the nurse with regard to the fact that she organizes the demand and, due lack of service organization, limits access to such service.

The nurse practices, in being conducted rigidly, without negotiation with users, with little involvement with their health situation and guided by pre-established standards, do not contribute to the resolution of the health needs of the population, and may generate dissatisfaction with regard to these practices as well as to the potential of nursing care.

In the process of health care provision, the practices developed should help address the needs of users with tools that transcend the implementation of technical and scientific knowledge, appropriating the political, organizational and symbolic fields, which means to focus the discussion on the mode through which the care has been provided in the daily routine of services. This aspect accounts, in large part, for the low impact of the actions produced and for the users' dissatisfaction in relation to the system, as a result of weaknesses such as the structuring of the health care network, which is still focused on procedures and valuation of biomedical knowledge and practices ${ }^{(16)}$.

A research showed that $\mathrm{PHC}$ users in England noted the expansion of the nurses' clinical practice, which resulted in better 
access to services, increased duration of appointments, more efficient communication, and adherence to treatment. It was also pointed out that the nurses attained a professional condition of greater respect, in addition to expanding the scope of their professional knowledge. In relation to the health system, emphasis on the cost savings and expansion of care, priority of the current period, in which there is demand for restricted budgets ${ }^{(7)}$.

The users' reports showed that the nurse conducts home care visits prioritizing persons who cannot go to the $\mathrm{FHU}$; in a more restricted way, preventive actions on breast and prostate cancer are implemented.

A study showed that sometimes the nurse faces the dilemma of meeting the statistical goals both for the home care visit and for the other activities of the health unit, resulting in fewer visits to meet such requirements, prioritizing the bedridden according to the criteria recommended by the Ministry of Health ${ }^{(22,6)}$.

Such findings seem to indicate that the practice of nurse care in home visiting is being used restrictively with little focus on health promotion actions, valuing biological aspects so these visits are carried out, which leads to a practice that is biologicist, fragmented and disconnected from the history and uniqueness of each individual, even if to meet the statistical goals established.

Human beings present paradoxes and ambiguities in selfcare and, sometimes, may present noncare behaviors ${ }^{(11)}$, which are more evident at home.

Thus, it is necessary to ensure working conditions for nurses to develop their practices in a broader perspective, with less rigidity in meeting goals guided by biological aspects, considering that the FHS philosophy emphasizes health promotion actions.

Reports from users also revealed that some nurses conduct no home care visits, which are carried out only by the Community Health Agents (CHA). Users also acknowledge that the family context contributes significantly to the dialogue with the nurse and report that the home visit could enhance the nurse care practice through the guidelines provided and the identification of health needs experienced by these users.

The conduct of home visit consists in the primary activity of the CHAs, and this professional develops the activities more closely to the users due to residing in the area served, enabling better condition to identify health needs of the community ${ }^{(23)}$.

With regard to nurses, it is observed that their practices cannot be restricted to the physical space of the FHU, without prioritizing the contact with the community and with the work of CHAs, which significantly contributes to the planning and execution of actions consistent with the reality experienced by users ${ }^{(23)}$.

The lack of home visit represents a problem in the health care of individuals, considering that it hinders the identification of the users' health needs, preventing the nurse from developing practices that enable research, guidance and intervention in situations that could be identified in the home context ${ }^{(22)}$.

When conducting the home visit, the nurse has the opportunity to know the users' social and family context, which is relevant to determine the weaknesses and possibilities in the process of taking care of themselves and of their families, fostering co-responsibility in their health care, as well as strengthening the bond between nurse and family. Therefore, the lack of home visit represents a weakness in the potential of nurse practice, and a (re)definition of nursing practices is relevant in order to stimulate changes in relation to such practices in the context of the FHS.

In order for the nurse care practices to achieve greater potentiality, it is necessary to reconsider their approach procedures and the appropriate means for their participation in health actions, including in the context of primary health care ${ }^{(12)}$.

In the study, users reported that educational activities are developed during the nurse appointment by means of dialogue and provision of guidelines that contribute to their health care, with regard to alimentation and walking. They also emphasized that the nurse shows willingness to explain, guide and answer their questions.

Health education is a fundamental element so the nurse care practice can promote health in primary care through an approach that can stimulate individual and collective changes, based on a dialogic relationship that focuses on those involved and, thus, fosters the users' autonomy, citizenship and co-responsibility ${ }^{2425)}$.

Taking that into consideration, it is important that nurses value the users' knowledge, their experiences and history, from the perspective of a dialogic relationship, which is not limited to transferring information or prescriptive guidelines, often out of the context of the users' everyday reality, in the perspective of the collective construction of healthier modes of health care.

The study also showed that some users do not participate in the educational activities carried out at FHUs, emphasizing that the community need to be more stimulated to participate in these activities.

The study shows that the non-participation of users in educational activities can be related to the schedule, which is not always compatible with their availability, indicating the relevance of the planning of the educational activities in conjunction with the community in order to set the appropriate schedule, topics to be covered, among others ${ }^{(26)}$.

In order for health education to be implemented effectively, it is necessary that nurses value each user's uniqueness, history, beliefs, experiences, among others, employing sensitive listening, warm care and respect for the human person, with a view to enhancing the user's autonomy based on the ethical and social commitment of care.

The study presented some limitations with regard to the reality of a municipality in the countryside of the state of Bahia, making it difficult to generalize the findings to other social contexts and suggesting the need for further research to explore the subject, in order to address other aspects which were not covered by the study.

The research also contributes to the nursing area considering its inclusion in the context of public policies in $\mathrm{PHC}$, which requires the strengthening of its care practices with a theoretical-philosophical framework, so as to foster the comprehensive health care considering the various knowledge and practices of users, professionals and health managers, in addition to the actors involved in the process of training in health.

\section{FINAL CONSIDERATIONS}

The study showed that the FHS nurse care practice presents permeated by listening, warm care and dialogue; however, 
such practice sometimes conveys authoritarianism and rigidity, causing moments of satisfaction and dissatisfaction of users in relation to the nurse care.

It is observed that the employment of relational technologies, in conjunction with the rational use of light and lighthard technologies, enables greater enhancement to nurse practices in relation to identifying and addressing the users' health needs, being in line with the proposal of the FHS.

However, it was shown that the nurse practice has characteristics of the biomedical model, which focuses on biological and technicist aspects, not valuing the users' sociohistorical context and the implications for their health.

Furthermore, it is pointed out that the non-conduct of home visit or its conduct focused on bedridden users evidences weaknesses in the nurse practice, considering the unique character of the home context for dialogue with users of health services.

The guidelines provided during the appointment, highlighted in the study, evidence the nurse's commitment to seek the dialogue in a more individualized manner, constituting an opportunity for closer interaction with users so as to identify their concerns and desires. Nevertheless, the health education actions seem to be carried out in a prescriptive manner, focusing on the biological aspect rather than on content that could stimulate the users' critical and political potential, with a view to fostering autonomy and citizenship.

Such findings lead to reflections on the need to evaluate the Ministerial Policies implemented in the country, considering that the pre-established goals and working conditions of health professionals often constitute obstacles to the development of practices committed to social transformation.

Fostering discussions on nurse training is also relevant so care is legitimized as the essence of such training, so as to consolidate in the nursing practice the ethical dimension of care, which may contribute significantly to value and redefine care as a structuring axis of their practices.

\section{REFERENCES}

1. Waldow VR. Cuidar: expressão humanizadora da enfermagem. Rio de Janeiro: Vozes; 2006.

2. Collière MF. Promover a vida: da prática das mulheres de virtudes aos cuidados de enfermagem. Lisboa: Lidel; 1999.

3. Carvalho V. About the professional identity in Nursing: punctual reconsiderations in philosophical vision. Rev Bras Enferm [Internet]. 2013[cited 2015 May 13];66(Esp):24-32. Available from: http://www.scielo.br/pdf/reben/v66nspe/ v66nspea03.pdf

4. Ramos DKR, Mesquita SKC, Galvão MCB, Enders BC. Health paradigms and (de)valorization of the nursing care. Enferm Foco [Internet]. 2013[cited 2016 Apr 20];4(1):414. Available from: http://revista.portalcofen.gov.br/index. php/enfermagem/article/view/501/191

5. Santos FPA, Nery AA, Matumoto S. Care provided to patients with hypertension and health technologies for treatment. Rev Esc Enferm USP [Internet]. 2013[cited 2016 May 13];47(1):107-14. Available from: http://www.scielo. br/pdf/reeusp/v47n1/en a14v47n1.pdf

6. Brasil. Ministério da Saúde. Portaria nº 2.488 de 21 de outubro de 2011. Aprova a Política Nacional de Atenção Básica, estabelecendo a revisão de diretrizes e normas para a organização da Atenção Básica, para a Estratégia Saúde da Família (ESF) e o Programa de Agentes Comunitários de Saúde (PACS). Diário Oficial da União; Poder Executivo, Brasília, DF, de 24 de outubro de 2011.

7. Toso BRGO, Filippon J, Giovanella L. Nurses' performance on primary care in the National Health Service in England. Rev Bras Enferm [Internet]. 2016[cited 2016 Apr 25];69(1):182-91. Available from: http://www.scielo.br/ pdf/reben/v69n1/en_0034-7167-reben-69-01-0182.pdf

8. Merhy EE. Saúde: a cartografia do trabalho vivo. $3^{\mathrm{a}}$ ed. São Paulo: Hucitec; 2007.

9. Saito DYTS, Zoboli ELCP, Schveitzer MC, Maeda ST. User, client or patient? which term is more frequently used by nursing students? Texto Contexto Enferm [Internet]. 2013[cited 2016 May 13];22(1):175-83. Available from: http://www.scielo.br/pdf/tce/v22n1/21.pdf

10. Bardin, L. Análise de Conteúdo. Lisboa: Edições 70; 2011.

11. Waldow VR. O cuidado na saúde: as relações entre o eu, o outro e o cosmos. Rio de Janeiro: Vozes; 2004.

12. Collière MF. Cuidar: a primeira arte da vida. Paris: Lusociência; 2001.

13. Brasil. Ministério da Saúde. Conselho Nacional de Saúde-CNS. Resolução n 466 de 12 de dezembro de 2012. Dispõe sobre as diretrizes e normas regulamentadoras de pesquisas envolvendo seres humanos. Brasília: Ministério da Saúde; 2012.

14. Neves EP. As dimensões do cuidar em enfermagem: concepções teórico-filosóficas. Esc Anna Nery Rev Enferm. 2002;6(Suppl.1):79-92.

15. Silva NC, Giovanella L, Mainbourg EMT. [The family in the practices of Family Health teams]. Rev Bras Enferm [Internet]. 2014[cited 2016 Apr 25];67(2):274-81. Available from: http://www.scielo.br/pdf/reben/v67n2/0034-7167-re ben-67-02-0274.pdf Portuguese

16. Assis MMA, Nascimento MAA, Pereira MJB, Cerqueira EM. Comprehensive health care: dilemmas and challenges in nursing. Rev Bras Enferm [Internet]. 2015[cited 2016 Apr 20];68(2): 333-8. Available from: http://www.scielo.br/pdf/ reben/v68n2/en_0034-7167-reben-68-02-0333.pdf

17. Oliveira MAC. [Re(thinking) nursing carative projects through the light of population health needs]. Rev Bras Enferm [Internet]. 2012[cited 2016 Apr 20];65(3):401-5. Available from: http://www.scielo.br/pdf/reben/v65n3/ v65n3a02.pdf Portuguese.

18. Oliveira MAC, Pereira IC. [Primary Health Care essential attributes and the Family Health Strategy]. Rev Bras 
Enferm [Internet]. 2013[cited 2016 Apr 25];66(Esp):15864. Available from: http://www.scielo.br/pdf/reben/ v66nspe/v66nspea20.pdf Portuguese.

19. Santos SVM, Motta ALC, Dázio EMR, Terra FS, Resck ZMR, Fava SMCL, et al. Entender El sentido de los cuidados em enfermería. Rev Cubana Enferm [Internet]. 2015[cited 2016 Jun 17];31(3):[aprox. 2 p]. Available from: http://www. revenfermeria.sld.cu/index.php/enf/article/view/619

20. Castro LMC, Oliveira EF, Pereira A, Camargo CL. Reflections about the everyday the life of a nurse. Rev Cubana Enferm [Internet]. 2014[cited 2016 Aug 17];30(1). Available from: http://www.revenfermeria.sld.cu/index.php/ enf/article/view/215

21. Borré-Ortiz YM, Lenis-Victoria C, Suárez-Villa M, Tafur-Castillo J. El conocimiento disciplinar en el currículo de enfermería: una necesidad vital para transformar la práctica. Rev Cienc Salud [Internet]. 2015[cited 2016 Aug 12];13(3):481-91. Available from: http://www.scielo.org. co/pdf/recis/v13n3/v13n3a11.pdf

22. Kebian LVA, Acioli, S. Home visits by Family Health Strategy nurses and community health agents. Rev Eletr Enf [Internet]. 2014[cited 2016 May 22];16(1):161-9. Available from: http://revistas.ufg.br/fen/article/view/20260

23. Jesus AS, Santos FPA, Rodrigues VP, Nery AA, Machado JC, Couto TA. Community health agent role: users' knowledge. Rev Enferm UERJ [Internet]. 2014[cited 2016 May 22];22(2):239-44. Available from: http://www.e-publicacoes. uerj.br/index.php/enfermagemuerj/article/view/13654

24. Mascarenhas NB, Melo CMM, Fagundes NC. [Production of knowledge on health promotion and nurse's practice in Primary Health Care]. Rev Bras Enferm [Internet]. 2012[cited 2016 May 13];65(6):991-9. Available from: http://www. scielo.br/pdf/reben/v65n6/a16v65n6.pdf Portuguese.

25. Acioli S, David HMSL, Faria MGA. Health education and nursing in public health: reflections on practice. Rev Enferm UERJ [Internet]. 2012[cited 2016 Apr 22];20(4):5336. Available from: http://www.e-publicacoes.uerj.br/index.php/enfermagemuerj/article/view/5695

26. Couto TA, Santos FPA, Rodrigues VP, Vilela ABA, Machado JC, Jesus AS. Health education under perspective of family health teams users. Rev Enferm UFPE [Internet]. 2016[cited 2016 May 22];10(5):1606-14. Available from: http://www.revista.ufpe.br/revistaenfermagem/index.php/ revista/article/view/9147/pdf_10142 